\title{
THE PRESIDENT/LE PRESIDENT
}

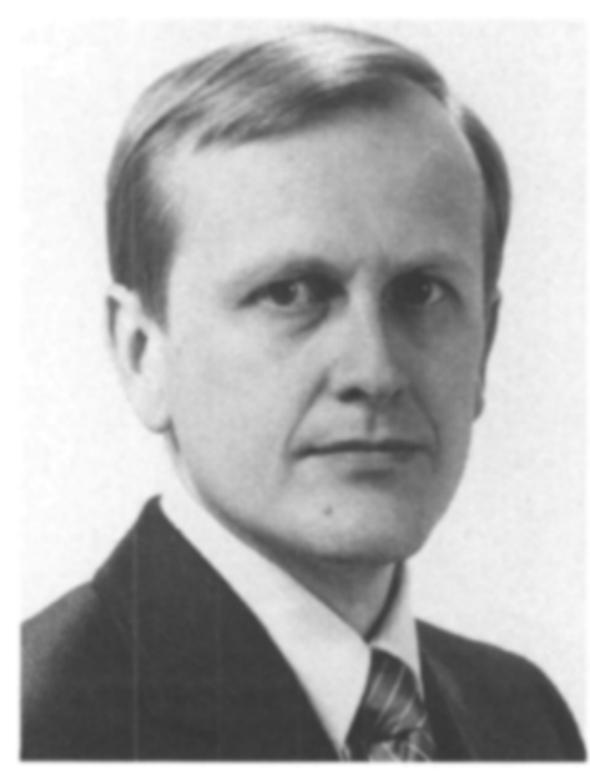

ERnest RoBert Michel, M.D., F.R.C.P.(C)

Dr. E.R. Michel of Toronto was installed as President of The Canadian Anaesthetists' Society on the occasion of the Annual Meeting of the Society at Quebec City on May 25th, 1982.

Dr. Michel graduated M.D. from The University of Toronto in 1965 . Following a rotating internship at New Mount Sinai Hospital in Toronto, he enrolled in the postgraduate programme in anaesthesia at The University of Toronto. He became a Fellow of the Royal College of Physicians and Surgeons of Canada in 1970 and was appointed Clinical Teacher in Anaesthesia on the staff of The Toronto General Hospital. He was promoted to Assistant Professor in 1974.

Dr. Michel was elected to the Council of the Society in 1976 representing the Ontario Division. In 1978 he was appointed to the Executive Committee as a representative of Council. He was elected Second Vice-President in 1980 and First Vice-President in 1981.

Dr. Michel was married to Barbara Lawrence in 1963. They have one son and one daughter. Extra-curricular interests are photography and flying.
Le docteur E.R. Michel de Toronto occupe le poste de président de la Société canadienne des anesthésistes depuis l'assemblée annuelle de la Société à Québec, le 25 mai 1982.

Le docteur Michel a obtenu son diplôme de docteur en médecine de l'université de Toronto en 1965. A la suite d'un internat rotatoire au New Mount Sinai Hospital de Toronto, il s'engagea dans le programme post-doctoral d'enseignement de l'anesthésie de l'université de Toronto. Il devint par la suite associé du Collège royal des médecins et chirurgiens du Canada en 1970 et fut nommé professeur $\mathrm{d}^{2}$ enseignement clinique tout en exerçant sa spécialité au Toronto General Hospital. Il devint professeur adjoint en 1974.

Le docteur Michel fut élu au conseil de la Société en 1976 comme représentant de la division ontarienne. En 1978, il devenait membre du comité exécutif en qualité de représentant du conseil. Il fut élu deuxième vice-président en 1980 et premier vice-président en 1981.

Le docteur Michel se maria à Barbara Lawrence en 1963. Ils ont un fils et une fille. En dehors de ses activités professionnelles, il s'intéresse à la photographie et à l'aviation. 